\title{
The Relationship Between Influenza Vaccine-Induced Specific Antibody Responses and Vaccine-Induced Nonspecific Autoantibody Responses in Healthy Older Women
}

\author{
You-Peng Huang,,$^{1,2}$ Laurent Gauthey, ${ }^{1}$ Martine Michel, ${ }^{3}$ Myriam Loreto, ${ }^{1}$ Michel Paccaud, ${ }^{4}$ \\ Jean-Claude Pechere, ${ }^{2}$ and Jean-Pierre Michel ${ }^{1}$
}

\author{
'Geriatric Institutions of Geneva University, Geriatric Hospital, Geneva, Switzerland \\ 2Department of Genetics and Microbiology, Geneva University. \\ ${ }^{3}$ Transfusion Center of Annemasse, France. \\ ${ }^{4}$ Public Health System, Virus Laboratory, Geneva.
}

\begin{abstract}
The effect of aging on human humoral immunity was investigated by studying in vivo the relationship between influenza specific antibody responses and nonspecific vaccine-induced autoantibody responses in 32 independent, well-nourished older women volunteers (mean age 86 yr, range 74-97) and 23 young women volunteers (mean age 34 yr, range 23-46). Anti-influenza A/Taiwan/1/86(HINI) antibody titers were determined by a hemagglutination inhibition test (HI-test), and serum anti-dsDNA antibodies were measured by ELISA prior to, 15, and 30 days after influenza vaccination. The mean postvaccination fold increase (FI) of the anti-influenza antibody response was significantly lower in elderly individuals as compared to younger individuals. In contrast, the mean anti-dsDNA autoantibody level measured 30 days after vaccination was significantly increased in older volunteers as compared to younger ones. There was a significant negative correlation between the level of the FI of the anti-influenza antibody response and the anti-dsDNA antibody response $(\mathrm{r}=-.441, \mathrm{p}<.01)$. Our results suggest that the altered influenza specific antibody response was associated with an age-related increase in autoimmunity in aging individuals.
\end{abstract}

$\mathrm{T}$ HE immunologic theory of aging is based on the hypothesis that immunologic changes, including a decline in specific immunity, may be responsible for the many manifestations of the aging process. In addition to the decline in specific immunity there is an increase in autoimmunity as demonstrated by the appearance of a variety of autoantibodies in the serum of elderly individuals (1-7).

The incidence of anti-deoxyribonucleic acid (DNA), anticardiolipin, anti-thyroid, anti-thyroglobulin, anti-immunoglobulins antibodies, rheumatoid factor, and antibodies to smooth muscle, mitochondria, and gastric parietal cells has all been shown to increase with age $(1,3,4,6-11)$. The presence of these autoantibodies has been reported to be associated with shortened survival in men and women $(12,13)$. However, the pathological or physiological significance of these autoantibodies in the elderly has not yet been determined.

Immune senescence appears to contribute to the increased susceptibility of the elderly to infectious diseases, to the decreased cell-mediated immunity, and to the limited effectiveness of immunization in this population (14-28). There is general agreement that influenza vaccine efficacy is lower in elderly as compared to younger individuals (27-29). However, in some studies, no difference or a better "response" to influenza vaccine in the elderly as compared to younger control subjects has been noted (27). The basis for these conflicting observations and interpretations concerning the relationship between aging and the response to influenza vaccination remains to be elucidated.

The present study was designed to investigate the relationship between increased autoimmunity and decreased specific immunity in aging individuals. Specifically, the relationship following vaccination between specific immunity induced by influenza vaccine (as determined by the presence of antiinfluenza A/Taiwan/l/86[H1Nl] antibodies in the serum) and vaccine-induced nonspecific autoantibody responses (as measured by serum levels of anti-double stranded DNA[dsDNA] antibodies) was evaluated. The results suggest that fundamental differences exist in the immune regulation of the specific anti-influenza antibody and nonspecific anti-dsDNA autoantibody responses in elderly individuals as compared to younger individuals, after influenza vaccination.

\section{METHODS}

Subjects. - Fifty-five healthy women volunteers participated in this investigation and gave their informed consent. They included 32 elderly (mean age $86 \mathrm{yr}$ ) independent, well-nourished women, and 23 young women (mean age 34 yr). No participants had taken any medication (including immunosuppressive drugs) in the week prior to the beginning of the study, and none had been vaccinated for influenza during the past 11 months. Venous blood samples were collected prior to, 15 , and 30 days after vaccination. 
All subjects received one dose of influenza vaccine $(0.5 \mathrm{ml})$ containing three types of influenza virus: A/Taiwan/1/ $86(\mathrm{H} 1 \mathrm{~N} 1), \mathrm{A} / \mathrm{Shanghai} / 11 / 87(\mathrm{H} 3 \mathrm{~N} 2)$, and influenza $\mathrm{B}$ Yamagata/16/88.

The influenza vaccine used was a commercially licensed inactivated whole virus vaccine (Inflexal Berna) manufactured by the Swiss Serum \& Vaccine Institute, Bern, Switzerland. The concentration of hemagglutinin for each strain was $20 / \mu \mathrm{g} / \mathrm{ml}$.

Serologic methods. - The serum anti-dsDNA antibody concentration was determined by a highly sensitive enzyme immunoassay (ELISA) (Anti(ds)DNA-Diagnostic ELISA Kit, PROGEN, Readysysteme AG, Switzerland) (30). The test was standardized with WHO-adjusted human standards. Sera samples were prepared and stored at $-70^{\circ} \mathrm{C}$. Immediately prior to analysis, they were diluted 1:200 (minimum dilution) with dilution buffer provided with the kit. The serum sample concentrations of anti-dsDNA antibodies $(\mu \mathrm{g} /$ $\mathrm{ml}$ ) or the binding activity in terms of anti-dsDNA antibodies (WHO-IUnits/ml) were calculated using a standard curve. The positive human standard had been standardized using two different WHO reference materials: (a) human IgG subclass proteins (WHO IgG Subcommittee), and (b) first international standard for anti-dsDNA antibody (coded Wo80). It was noted that 10 WHO-IUnits $/ \mathrm{ml}=1 \mu \mathrm{g} / \mathrm{ml}$. Concentrations greater than $50 \mathrm{WHO}-\mathrm{IU} / \mathrm{ml}(5 \mu \mathrm{g} / \mathrm{ml})$ were considered to be strongly positive. The antibodies against dsDNA or single-stranded DNA(ssDNA) of control sera samples were quantitated by modified Farr assays as described (31).

The hemagglutination-inhibition test (HI-Test) was performed with sera inactivated at $56^{\circ} \mathrm{C}$ for $40 \mathrm{~min}$ immediately prior to the HI-test. The sera were treated with cholera filtrate (Sigma Chemical Co., St Louis, MO) in order to destroy serum nonspecific hemagglutinin (HA) inhibitors (32), and absorbed with chicken red blood cells. The HItests were performed in 96-well V-shaped microtrays (Greiner, ABS, Geneva, Switzerland). A standard method/ procedure has been previously described (32).

Statistical methods. - The geometric mean serum concentration of anti-influenza A/Taiwan/1/86(H1N1)-HI antibodies (HI-AB) was calculated. The arithmetic mean for antidsDNA antibodies was determined. The significance of differences between the mean serum concentration of the two types of antibodies in older and younger individuals was analyzed using Student's $t$-test. Linear regression analysis was used to study the relationship between the fold increase (FI) of anti-influenza A/Taiwan/1/86(HINl)-HI antibody (FI of $\mathrm{HI}-\mathrm{AB}$ ) response and anti-dsDNA antibody response. The FI of $\mathrm{HI}-\mathrm{AB}$ response was calculated as follows: the highest titer of serum $\mathrm{HI}-\mathrm{AB} 15$ or 30 days after vaccination divided by the titer of $\mathrm{HI}-\mathrm{AB}$ prior to vaccination.

\section{RESULTS}

Anti-influenza A/Taiwan///86(HINI) antibody response. - The nature of the specific in vivo anti-influenza antibody response was evaluated by determining the serum titers of anti-influenza A/Taiwan/1/86(H1N1) antibodies using a hemagglutination inhibition test in which the antibody inhibition activity (HI-AB) was expressed as serum antibody dilution titers. The anti-viral hemagglutinin (HA) antibody plays a major role in protection against influenza in relation to virus neutralization (33-35). The time-course of the antibody response is shown in Figure 1. Prior to vaccination the mean serum titer of anti-influenza A/Taiwan/1/ $86(\mathrm{H} 1 \mathrm{~N} 1)-\mathrm{HI}$ antibodies (HI-AB) tended to be higher in the group of older subjects than in the younger group, but the differences were not statistically significant. Following vac-

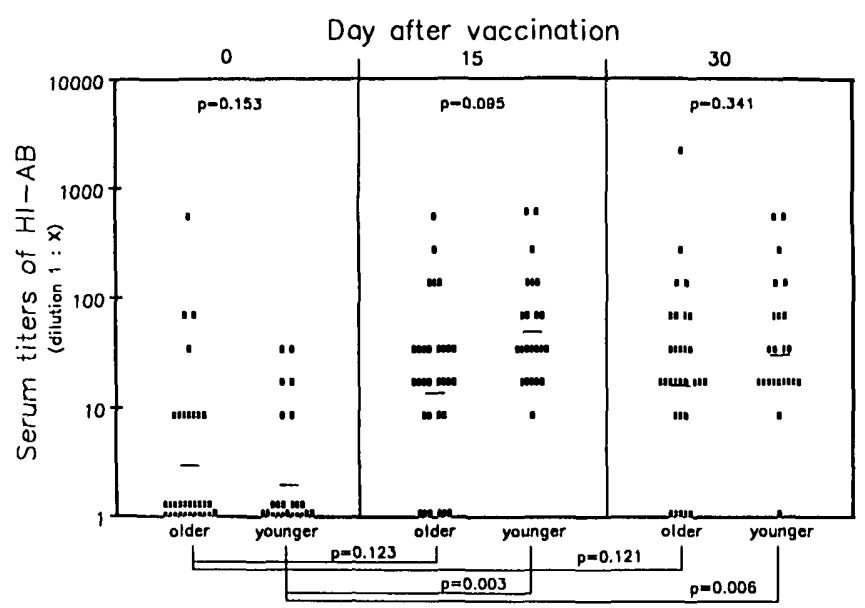

Figure 1. Comparison of serum anti-influenza A/Taiwan/1/86(H1NI) antibody levels (HI-AB) before and 15 and 30 days after influenza vaccination, in elderly and young subjects. The bars indicate the geometric mean.

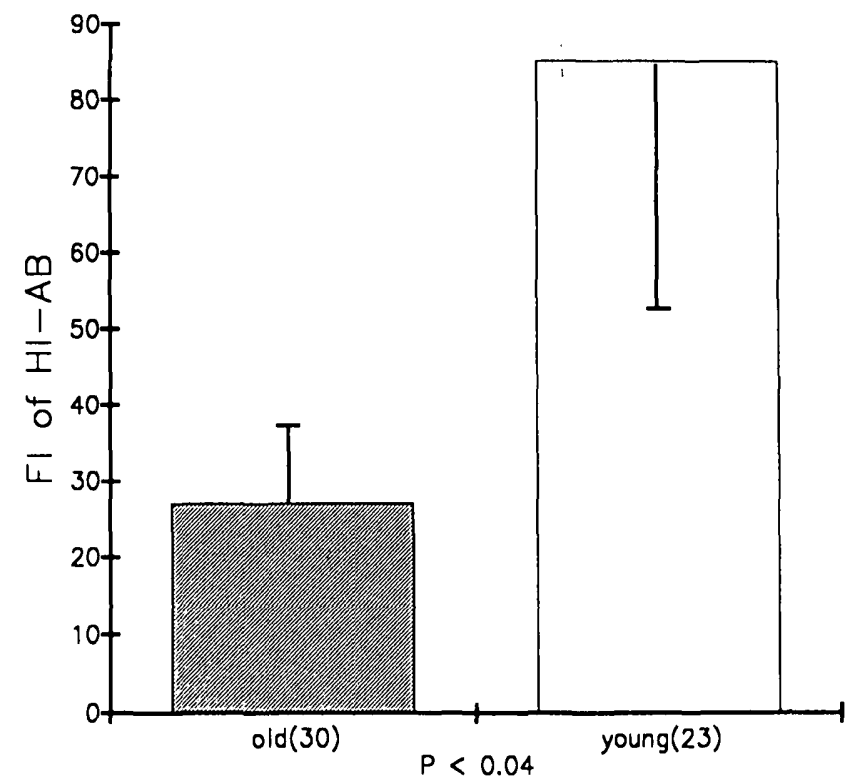

Figure 2. Comparison of the fold increase $(\mathrm{FI})$ in the anti-influenza $\mathrm{A}$ / Taiwan/1/86( $\mathrm{H} / \mathrm{N} 1)$ antibody response ( $\mathrm{Fl}$ of $\mathrm{HI}-\mathrm{AB})$ after influenza vaccination in elderly and young subjects. The FI of HI-AB based on the titer of serum $\mathrm{HI}-\mathrm{AB}$ at day 15 or 30 after influenza vaccination divided by the titer of serum HI-AB prior to vaccination. The error bars correspond to the mean $\pm S E M$ of $\mathrm{FI}$ of $\mathrm{HI}-\mathrm{AB}$ in older and young groups. The number of subjects studied is shown in parentheses. The mean $\mathrm{FI}$ of $\mathrm{HI}-\mathrm{AB}$ response in older individuals was significantly decreased as compared to younger individuals $(p<.04)$. 
cination in younger subjects there was a significant increase in the serum HI-AB titers at 15 and 30 days as compared to the serum titers prior to vaccination $(p=.0028$ at 15 days, $p$ $=.0064$ at 30 days). In contrast, the serum antibody titers in older subjects were not significantly increased 15 and 30 days after vaccination.

When the geometric mean HI-AB levels of older and younger individuals were compared, no differences were observed between the two groups prior to vaccination or 15 and 30 days after vaccination. However, when the results were expressed in terms of the fold increase (FI) of the HI$\mathrm{AB}$ response, a measure of the current vaccine-induced specific humoral immune response, important differences in the antibody responses between the two age groups were observed (Figure 2). Specifically, the mean FI in younger subjects was significantly greater than the mean FI of older subjects $(p=.039)$. These results demonstrated that older subjects have a reduced specific immune response to influenza A/Taiwan/1/86(H1N ) antigen as compared to younger subjects, even though they may have higher initial levels of serum HI-AB (see Figure 1). In contrast, young individuals had lower initial serum levels of HI-AB which were significantly increased following vaccination, as expressed by the FI. Therefore, while the absolute levels of the HI-AB were not statistically significantly different between the two groups (Figure 1), the levels of the current specific immune responses were quite different (Figure 2).

The immune response to influenza vaccine was further investigated by determining the number of individuals who did not respond to the vaccination. A "nonresponder" was defined as an individual with an FI equal to or less than 2. There were $33 \%$ and $9 \%$ nonresponders in the older and younger groups, respectively. Therefore, the capacity of elderly individuals to respond to the vaccine was decreased, and a greater number of them were nonresponders.

The antibody responses to influenza A/Shanghai/11/ $87(\mathrm{H} 3 \mathrm{~N} 2)$ and B Yamagata/16/88 were also significantly decreased in the elderly in terms of the FI as compared to young controls (data not shown). For the purpose of analyzing the relationship between antigen specific response and nonspecific autoantibody response following influenza vaccination, only the data obtained from one virus strain (A/ Taiwan/1/86[H1N1]) have been presented. This strain, a relatively old virus (1986) (as compared to A/Shanghai/11/ 87 and B Yamagata/16/88), was isolated from patients in Switzerland in 1987, 1988, and 1989. Therefore, most individuals in our study, in both the young and old groups, may have had specific memory $\mathrm{T}$ cells for A/Taiwan/1/ 86(HIN1) epitopes. The other two strains (A/Shanghai/11/ 87 and B Yamagata/16/88 viruses) appeared in Switzerland after 1989. This we considered too close to the time (1990) when we started this investigation.

Serum anti-dsDNA antibodies in elderly and young individuals. - The serum anti-dsDNA antibody concentration was determined by a commercially available sensitive standardized (ELISA) assay. Quantitative analysis could be performed due to the availability of positive standards with a defined human antibody concentration. According to the reference range provided with the kit (Progen, Ready-
Systeme, AG) anti-dsDNA antibody concentrations of 25 $50 \mathrm{WHO}-\mathrm{IU} / \mathrm{ml}$ (equal to $2.5-5 \mu \mathrm{g} / \mathrm{ml}$ ) were considered to be weakly positive, whereas antibody concentrations greater than $50 \mathrm{WHO}-\mathrm{IU} / \mathrm{ml}(5 \mu \mathrm{g} / \mathrm{ml})$ were strongly positive. For the purpose of this study the threshold of positive level was defined as $30 \mathrm{WHO}-\mathrm{IU} / \mathrm{ml}$. This was based on the observation that more than $95 \%$ of normal young women controls had serum anti-dsDNA antibody levels below this value. Eleven of $32(34 \%)$ of older individuals had positive serum anti-dsDNA antibody levels (values greater than 30 WHO$\mathrm{IU} / \mathrm{ml}$ ) prior to vaccination (Figure 3 ) compared to 1 of 23 $(4 \%)$ of younger individuals. The concentration (mean \pm 1 $S D$ ) of anti-dsDNA antibodies was significantly increased in elderly as compared to younger individuals $(23.55 \pm 11.05$ and $12.84 \pm 9.0, p<.001)$, respectively.

Most antibodies defined as reactive with dsDNA recognize the deoxyribose phosphate backbone of the DNA and are therefore also capable of reacting with ssDNA(36). The following control sera were used to detect the presence of cross-reactions of this type and to verify the specificity of the anti-dsDNA antibody test (kits): (a) Two samples from patients with rheumatoid arthritis (RA) that were strongly positive for anti-ssDNA antibodies, negative for antidsDNA antibodies by the Farr assay, and negative for antidsDNA antibodies in the sera $(20,16 \mathrm{WHO}-\mathrm{IU} / \mathrm{ml})$ by dsDNA ELISA-Kit; (b) Two selected sera from patients with systemic lupus erythematosus that had high levels of antidsDNA antibodies ( $40,65 \%$ binding activity) but no evidence of ssDNA as demonstrated by the Farr assay also showed strong positive anti-dsDNA antibodies $(>400,350$ WHO-IU/ml) by the dsDNA ELISA-Kit.

The study of changes in the concentration of serum antidsDNA autoantibodies following vaccination revealed a significant increase in the level of anti-dsDNA antibody 30 days after vaccination compared with the level before vaccination in both old and young age groups $(p<.001$ in both)

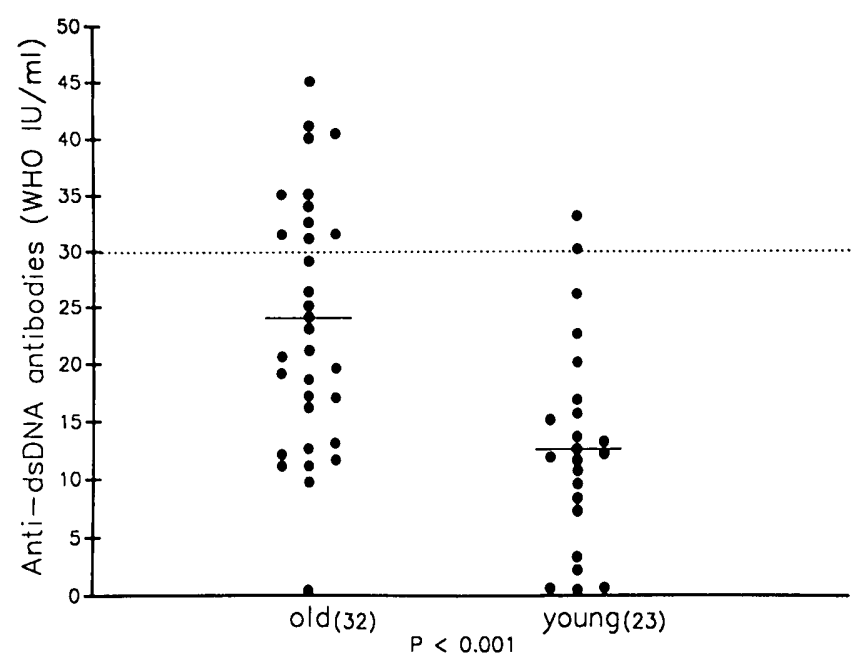

Figure 3. Distribution of anti-dsDNA antibodies in elderly and young individuals. The results are expressed in WHO standard units (WHO-IU/ $\mathrm{ml}$ ). The bars indicate the mean of anti-dsDNA antibodies in each group. The number of subjects studied is shown in parentheses. The dashed line indicates the threshold of positive level, defined as $(30 \mathrm{WHO}-\mathrm{IU} / \mathrm{ml})$. 
(Table 1). In addition, 30 days after vaccination, the mean serum level of anti-dsDNA antibodies in the elderly group was significantly greater (mean $\pm 1 S D: 52.28 \pm 35.04$ WHO-IU/ml) than the mean serum concentration of the antidsDNA antibody in the younger group $(32.32 \pm 16.31$ $\mathrm{WHO}-\mathrm{IU} / \mathrm{ml}, p<.01)$. The number of individuals considered positive for anti-dsDNA antibodies was increased at 30 days after vaccination in both groups $(77 \%$ in old, $44 \%$ in young). Thus, vaccination with influenza vaccine induced or enhanced the appearance of anti-dsDNA antibodies in both groups, but the effect was more pronounced in the older age group (greater proportion of positive individuals and higher serum concentrations). The relationship between influenza vaccine-induced specific antibody responses and influenza vaccine-induced nonspecific autoantibody responses in healthy older people was evaluated by linear regression analysis. There was a significant negative correlation between the FI of HI-AB and the anti-dsDNA antibody concentration (30 days after vaccination) in elderly $(r=-.441, p$ $<.01$ ) (Figure 4), as well as in the group of all individuals (elderly and young, $n=53, r=-.360, p=.01$ ). There was no significant correlation between the levels of antidsDNA antibody prior to vaccination and the titers of $\mathrm{HI}-\mathrm{AB}$ 15 or 30 days after vaccination $(r=-.251, p>.10$ and $r$ $=-.158, p>.10)$ respectively.

Since $66 \%$ of the older and $96 \%$ of the younger individuals had weakly positive or negative anti-dsDNA antibody levels $(<30 \mathrm{WHO}-\mathrm{IU} / \mathrm{ml}$ ) prior to vaccination (see Figure 3 ), it was not possible to study the relationship between the change in anti-dsDNA antibody levels and change in antiinfluenza antibody levels. Although the dsDNA-ELISA test employed in this study has a relatively high specificity and sensitivity, nonspecific binding can not be excluded at the low antibody level in ELISA.

\section{DISCUSSION}

Conflicting results have been previously reviewed concerning the association between old age and the specific antibody response to influenza vaccine in 17 independent studies during the period 1968-1988 (27). Some reports have demonstrated a reduced response in older subjects (2629). In contrast, others have found little or no difference or, on occasion, "better" responses as compared with younger subjects (27). These differences may be explained in part by different technical and analytical methods employed in the various studies. For example, the direct comparison of absolute serum anti-influenza antibody levels in old and young groups after vaccination may not take into account the possibility of an enhanced response in some individuals, who had been either previously vaccinated against influenza or exposed to influenza virus antigen in the environment. In our study, $34 \%$ of elderly individuals had detectable levels of $\mathrm{HI}-\mathrm{AB}$ prior to vaccination (HI-test titer $\geqslant 1: 8$, range $1: 8-$ 512) compared to $26 \%$ of younger individuals (range 1:832 ). The mean serum level of HI-AB before vaccination was greater in the older age group than in the younger age group.

Prior exposure to influenza viral antigens leading to a subsequent antibody response may also complicate the evaluation of the current antibody response to the vaccine. We, therefore, evaluated the antibody response in terms of the
Table 1. Serum Levels of Anti-dsDNA Antibodies in Recently Vaccinated Individuals (WHO-IU/ml)

\begin{tabular}{cccc}
\hline & \multicolumn{2}{c}{ Days After Vaccination } & \\
\cline { 2 - 3 } Subjects & 0 & 30 & p-value* \\
\hline Old & $n=32$ & $n=30$ & $<.001$ \\
Mean $\pm S D$ & $23.55 \pm 11.05$ & $52.28 \pm 35.04$ & \\
Young & $n=23$ & $n=23$ & $<.001$ \\
Mean $\pm S D$ & $12.84 \pm 9.0$ & $32.32 \pm 16.31$ & \\
\hline
\end{tabular}

*Statistical analysis of difference between antibody levels before and after vaccination by $t$-test.

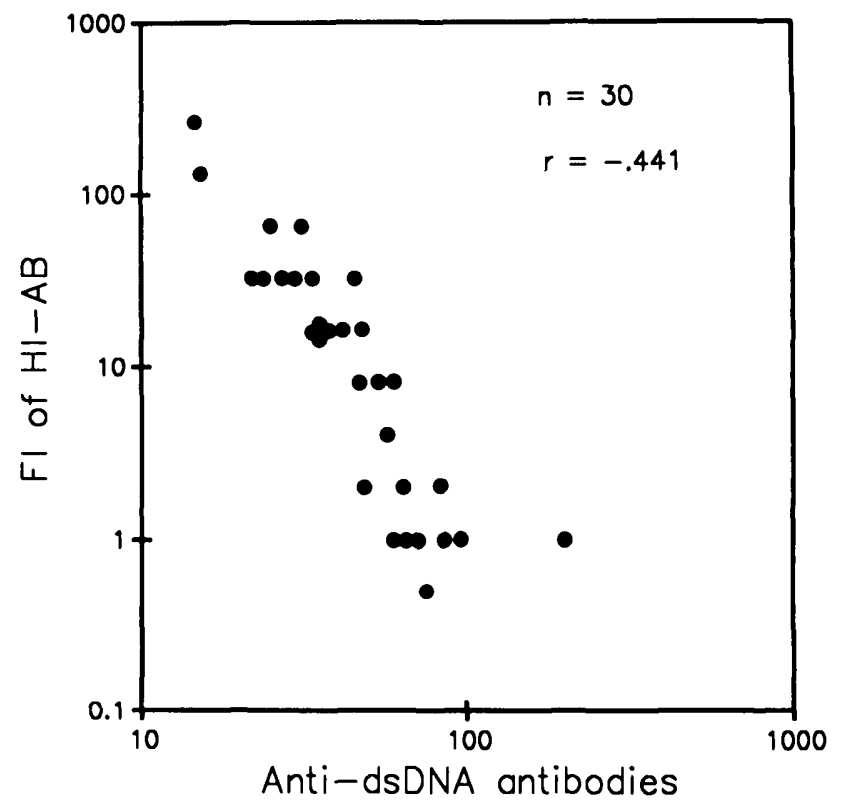

Figure 4. Correlation between the FI of $\mathrm{HI}-\mathrm{AB}$ and the serum antidsDNA antibodies ( 30 days after influenza vaccination) in elderly subjects.

fold increase (FI), a parameter which reflects the current anti-influenza antibody response, instead of using the absolute serum titer of anti-influenza antibody. Although no significant difference between the quantitative titers of the serum $\mathrm{HI}-\mathrm{AB}$ in the older and younger age groups could be demonstrated at 15 and 30 days after vaccination, we were able to detect significant differences in the specific antibody response between elderly women and younger ones.

Postvaccination serum anti-influenza antibodies may originate from three sources: (a) anti-influenza antibodies from previous vaccination or infection; (b) specific anti-influenza antibody responses induced by the current influenza vaccination; and (c) nonspecific polyclonal stimulation by influenza virus (vaccine) undergoing antigenic shift and drift. Memory $\mathrm{T}$ helper cells stimulated by influenza virus hemagglutinin (HA) show a broader pattern of recognition than do antiinfluenza antibodies (37). This could form the basis of a memory response to a new influenza virus infection.

The proportion of nonresponders to the current influenza vaccination was greater $(33 \%)$ in elderly as compared to younger $(9 \%)$ women. However, $67 \%$ of older individuals still belong to the responder category. Therefore, influenza 
vaccination is recommended for use in older populations because it also has been demonstrated to reduce symptomatic influenza infection in older people: $84 \%$ in the unvaccinated compared to $39 \%$ in vaccinated individuals $(38,39)$.

Nine percent of younger individuals were classified as nonresponders. The basis for this is unknown, but may be related in part to genetic factors, as has been previously demonstrated for hepatitis B vaccine (40).

In contrast to the decrease in specific immunity, our results confirm the increase in autoimmunity in healthy elderly people as demonstrated by the appearance of various serum autoantibodies including anti-dsDNA antibodies (1$11,41)$. Some investigations have shown that as many as $77 \%$ of healthy elderly individuals have at least one of the following serum autoantibodies (anti-ssDNA, anti-dsDNA, anti-cardiolipin, ANA autoantibodies and RF) (4). In the current study, $34 \%$ of healthy elderly women had a significant increase in anti-dsDNA antibody levels before vaccination as compared to $4 \%$ of younger women.

The presence of anti-dsDNA antibodies is highly specific for SLE (42-45); however, the incidence of SLE is not increased in the elderly (46). Although the mean level of serum anti-dsDNA antibodies in elderly subjects was significantly higher than in younger controls before and after vaccination in this study, it was still much lower than the serum levels of anti-dsDNA antibody measured in two active SLE patients.

Influenza virus can induce the transient appearance of anti-dsDNA antibodies (47-50). In general, these transient rises in autoantibodies after antiviral immunization are not harmful, whereas in other circumstances viral immunization may be followed by the appearance of or exacerbation of autoimmunity (Y.P. Huang and J.P. Michel, manuscript in preparation).

The mean serum level of anti-dsDNA antibodies was increased by 2.22 times in the older age group and 2.51 times in the younger age group 30 days after vaccination. This does not necessarily imply that the effect of influenza vaccine on inducing anti-dsDNA antibodies was similar in the two groups. In fact, the capacity of the anti-dsDNA antibody response was higher in elderly than in younger individuals, even though the mean serum levels of antidsDNA antibodies in elderly individuals prior to vaccination were 1.8 times greater than the levels in younger individuals. This suggests that elderly women had significantly greater numbers of activated $B$ cells than younger ones, and that a greater proportion of the B-cell repertoire (including resting $B$ cells) was committed to the production of anti-dsDNA antibodies. Following vaccination, the proportional increase in the number of B cells secreting anti-dsDNA antibodies was similar in the two groups, but the absolute number of activated anti-dsDNA antibody-secreting B cells was significantly greater in older women.

Finally, there was a significant negative correlation between influenza vaccine-induced specific antibody responses and the influenza vaccine-induced or enhanced anti-dsDNA antibody responses that occurred 30 days after vaccination. The influenza vaccine-induced specific antibody responses and nonspecific autoantibody responses occurred simultaneously. Some individuals, termed nonresponders, had low levels of specific antibody but elevated levels of anti-dsDNA antibody 30 days after vaccination. The data suggest that both the specific and nonspecific antibody responses share the same or closely related activated immune response systems. However, the mechanisms of induction of specific and nonspecific antibody responses appear to be different. Most elderly individuals who had impaired specific immunity in response to influenza vaccine had increased nonspecific autoantibody responses after vaccination.

In conclusion, the study of the effect of aging on the humoral immune response revealed that fundamental changes occur in the immune regulation of specific antibody and nonspecific autoantibody responses with age. The same immunogen may induce different responses in the elderly and in the young. Our results suggest that age-related increases in autoimmunity are associated with altered specific immune responses in aging individuals. Age-related changes in immune regulation appear to be an important feature in immune senescence.

\section{ACKNOWLEDGMENTS}

We would like to thank Prof. Dr. Jean Michel Dayer and Dr. Jonathan Weintraub for helpful discussions, and Odile Baumer for laboratory assistance.

Address correspondence and requests for reprints to Dr. You-Peng Huang, Department of Genetics and Microbiology, Geneva University C.M.U., 9, Av de Champel, 1211 Geneva 4, Switzerland.

\section{REFERENCES}

1. Hallgren HM, Buckley CE III, Gilbertsen VA, Yunis EJ. Lymphocyte phytohemagglutinin responsiveness, immunoglobulins and autoantibodies in aging humans. J Immunol 1973;111:1101-7.

2. Fixa B, Komarkova O, Nozicka Z. Ageing and autoimmunity. Gerontologia 1975;21:117-23.

3. Delespesse G, Gausset PH, Sarfati M, Dubi-Rucquoy M, Debisschop MJ, Van Haelst L. Circulating immune complexes in old people and in diabetics: correlation with autoantibodies. Clin Exp Immunol 1980;40:96-102

4. Manoussakis MN, Tzioufas AG, Silis MP, Pange PJE, Goudevenos J, Moutsopoulos HM. High prevalence of anti-cardiolipin and other autoantibodies in a healthy elderly population. Clin Exp Immunol 1987;69:557-65.

5. Meredith PJ, Walford RL. Autoimmunity, histocompatibility, and aging. Mech Ageing Dev 1979;9:61-77.

6. Hijmans W, Radl J, Bottazzo GF, Doniach D. Autoantibodies in highly aged humans. Mech Ageing Dev 1984;26:83-9.

7. Schuller E, Allinquant B, Rebout J, Fournier C, Dardenne M, Bach JF. Immunological studies in human ageing. II. Associated increase in anti-RNA and anti-DNA antibodies. J Clin Lab Immunol 1981;6: $107-10$.

8. Ockhuizen TH, Pandey JP, Galbraith GMP, Fudenberg HH, Hames CG. Autoantibodies and immunoglobulin allotypes in healthy North American Blacks of different age groups. Mech Ageing Dev 1982; 19:103-11.

9. Sawin CT, Bigos ST, Land S, Bacharach P. The aging thyroid: Relationship between elevated serum thyrotropin level and thyroid antibodies in elderly patients. Am J Med 1985;79:591-5

10. Zanussi $C$, Rugarli $C$, Casali $P$, et al. Immunological status of aged subjects with reference to serological evidence of autoimmunity. Ric Clin Lab 1977;7:115-23.

11. Rosenthal MJ, Hunt WC, Garry PJ, Goodwin JS. Thyroid failure in the elderly: Microsomal antibodies as discriminant for therapy. JAMA 1987;258:209-13.

12. Hooper B, Wittingham S, Mathews JD, Mackay IR, Curnow DH Autoimmunity in a rural community. Clin Exp Immunol 1972;12: 79-87. 
13. Mackay IR. Ageing and immunological function in man. Gerontologia 1972;18:285-304

14. Felser JM, Raff MJ. Infectious diseases and aging: immunologic perspectives. J Am Geriatr Soc 1983;31:802-7.

15. Alling DW, Blackwelder WC, Stuart-Harris ChH. A study of excess mortality during influenza epidemics in the United States. 1968-1976. Am J Epidemiol 1981;113:30-43.

16. Barker WH, Mullooly JP. Impact of epidemic type A-influenza in a defined adult population. Am J Epidemiol 1980;112:798-811.

17. Hall WN, Goodman RA, Noble GR, Kendal AP, Steece RS. An outbreak of influenza B in an elderly population. J Infect Dis 1981; 144:297-302.

18. Monto AS. Influenza: quantifying morbidity and mortality. Am J Med 1987;82(suppl 6A):20-5.

19. Kishimoto $S$, Tomino S, Mitsuya H, Fujiwara H, Tsuda H. Agerelated decline in the in vitro and in vivo synthesis of anti-tetanus antibody in humans. J Immunol 1980;125:2347-52.

20. Cook JM, Gualde N, Hessel L, et al. Alterations in the human immune response to the hepatitis $B$ vaccine among the elderly. Cell Immunol 1987;109:89-96.

21. Goodwin JS, Searles RP, Tung KSK. Immunological responses of a healthy elderly population. Clin Exp Immunol 1982;48:403-10.

22. Hallgren HM, Kersey JH, Dubey DP, Yunis EJ. Lymphocyte subsets and integrated immune function in aging humans. Clin Immunol Immunopathol 1978;10:65-78.

23. Czlonkowska A, Korlak J. The immune response during aging. J Gerontol 1979;34:9-14

24. Levine M, Beattie BL, McLean DM, Corman D. Characterization of the immune response to trivalent influenza vaccine in the elderly men. $J$ Am Geriatr Soc 1987;35:609-15.

25. Ruben FL. Prevention and control of influenza: role of vaccine. Am J Med 1987;G2(April 2):31-4.

26. Ershler WB. Influenza vaccination in the elderly: Can efficacy be enhanced? Geriatrics 1988;43:79-83.

27. Beyer WEP, Palache AM, Baljet M, Masurel N. Antibody induction by influenza vaccines in the elderly: a review of the literature. Vaccine 1989;7:385-94.

28. Keren G, Segev S, Morag A, Zakay Rones Z, Barzilai A, Rubinstein E. Failure of influenza vaccination in the aged. J Med Virol 1988; 25:85-9.

29. Frame PS. Is routine influenza immunization indicated for people over 65 years of age? J Fam Pract 1988;26:215-7.

30. Scheer U, Messner K, Hazan R, et al. High sensitivity immunolocalization of double and single-stranded DNA by a monoclonal antibody. Eur J Cell Biol 1987;43:358-71

31. Izui S, Lambert PH, Miescher PA. Determination of anti-DNA antibodies by a modified 125I-labelled DNA-binding test. Clin Exp Immunol 1976;26:425-30.

32. Palmer DF, Coleman MT, Dowdle WR, Schild GC. Advanced laboratory techniques for influenza diagnosis. Immunology series No 6. U.S. Department of Health, Education and Welfare. Atlanta, GA: Centers for Disease Control (CDC), 1975.

33. Hobson D, Curry RL, Beare AS. Hemagglutination-inhibiting anti- body titres as a measure of protection against influenza in man. Immunobiol Stand 1973;20:164-8.

34. Potter CW. Determinants of immunity to influenza infection in man. B Med Bull 1979;35:69-75.

35. Weis W, Brown JH, Cusack S, Paulson JC, Skehel JJ, Wiley DC. Structure of the influenza virus haemagglutinin complexed with its receptor, sialic acid. Nature 1988;333:426-31.

36. Tan EM. Antinuclear antibodies: Diagnostic markers for autoimmune diseases and probes for cell biology. Adv Immunol 1989;44:93-151.

37. Brown LE, Katz JM, French RA, Anders EM, White DO. Characterization of subtype-specific and cross-reactive helper-T cell clones recognizing influenza virus hemagglutinin. Cell Immunol 1987;109. $12-24$

38. Meiklejohn G, Hall $H$. Unusual outbreak of influenza A in Wyoming nursing home. J Am Geriatr Soc 1987;35:742-6.

39. Meiklejohn G, Hoffman R, Graves P. Effectiveness of influenza vaccine when given during an outbreak of influenza $A / H 3 N 2$ in nursing home. J Am Geriatr Soc 1989;37:407-10.

40. Alper CA, Kruskall MS, Marcus-Bagley D, et al. Genetic prediction of nonresponse to hepatitis B vaccine. N Engl J Med 1989;321:708-12.

41. Cammarata RJ, Rodnan GP, Fennell RH. Serum anti- $\gamma$-globulin and antinuclear factors in the aged. JAMA 1967;199:455-8.

42. Swaak AJG, Aarden LA, Statius van Eps LW, Feltkamp TEW. AntidsDNA and complement profiles as prognostic guides in systemic lupus erythematosus. Arth Rheum 1979;22:226-35.

43. Eaton RB, Schneider G, Schur PH. Enzyme immunoassay for antibodies to native DNA: specificity and quality to antibodies. Arth Rheum 1983;26:52-62.

44. Weinstein A, Bordwell B, Stone B, Tibbetts C, Rothfield NF. Anti bodies to native DNA and serum complement (C3) levels: application to diagnosis and classification of systemic lupus erythematosus. Am J Med 1983;74:206-16.

45. Tzioufas AG, Manoussakis MN, Drosos AA, Silis G, Gharavi AE, Moutsopoulos HM. Enzyme immunoassays for the detection of IgC and IgM anti-dsDNA antibodies: clinical significance and specificity. Clin Exp Rheumatol 1987;5:247-53

46. Catoggio LJ, Skinner RP, Smith G, Maddison PJ. Systemic lupus erythematosus in the elderly: clinical and serological characteristics. J Rheumatol 1984;11:175-81.

47. Portocala R, Spyrou N, Lambropoulou V, Pateraki E. Presence of both virus-specific and autoantibodies in the sera from patients with adenovirus and influenza B. Virologie 1988;39:207-16.

48. Maisch B, Trostel-Soeder R, Stechemesser E, Berg PA, Kochsiek K Diagnostic relevance of humoral and cell-mediated immune reactions in patients with acute viral myocarditis. Clin Exp Immunol 1982; 48:533-45.

49. Niwa Y, Sakane T, Kanoh T, Shichijo S, Wiederhold MD, Yokoyama MM. Transient autoantibodies with elevated complement levels in common viral diseases. J Clin Lab Immunol 1984;13:183-8.

50. Schattner A, Rager-Zisman B. Virus-induced autoimmunity. Rev Infect Dis 1990;12:204-22.

Received February 1, 1991

Accepted July 31, 199

\section{INSTRUCTIONS FOR AUTHORS}

Copies of the Journal of Gerontology: Medical Sciences Instructions for Authors, published in the January 1992 issue, are also available from Bettie L. Donley, Publications Coordinator, The Gerontological Society of America, 1275 K Street, N.W., Suite 350, Washington, DC 20005-4006. 